\title{
PENGARUH PENILAIAN PEMBIAYAAN TERHADAP KEPUTUSAN PEMBERIAN PEMBIAYAAN KREDIT MOBIL PADA PT. TRIHAMAS FINANCE CABANG MADIUN
}

\author{
Purwanto $^{1)}$, Apriyanti ${ }^{2)}$ \\ 1) Program Studi Manajemen Ekonomi \\ Universitas PGRI Madiun \\ ${ }^{2)}$ Dosen Universitas PGRI Madiun
}

\begin{abstract}
This study aimed to obtain findings about the influence eksplanitif tested financing vote against the decision to grant credit. This study uses a quantitative research design causal. The subjects were Pt. TrihamasMadiun branch and its object is the credit assessment and lending decisions are collected using a questionnaire and analyzed using multiple linear regression analysis. The results showed that the assessment of financing postitif $5 C$ and significant influence lending decisions.
\end{abstract}

Keywords: Assessment of financing, lending decisions.

\section{PENDAHULUAN}

$\begin{array}{cr}\text { Sebagaimana } & \text { umumnya } \\ \text { negara } & \text { berkembang, }\end{array}$ pembiayaan dunia usaha Indonesia masih didominasi oleh penyaluran kredit perbankan yang diharapkan dapat mendorong pertumbuhan ekonomi. Penyaluran kredit memungkinkan masyarakat untuk melakukan investasi, distribusi, dan juga konsumsi barang dan jasa, mengingat semua kegiatan investasi, distribusi, dan konsumsi selalu berkaitan dengan penggunaan uang. Kelancaran kegiatan investasi, distribusi, dan konsumsi ini tak lain adalah kegiatan pembangunan perekonomian masyarakat. Melalui fungsi ini bank berperan sebagai Agent of Development (Triandaru, 2006 : 9). Sehubungan dengan hal tersebut, Usaha Mikro Kecil dan Menengah (UMKM) merupakan mayoritas pelaku usaha di Indonesia dalam menjalankan usahanya, persoalan finansial khususnya.

Kegiatan sewa guna usaha ( leasing) diperkenalkan untuk pertama kalinya di Indonesia pada tahun 1974 dengan dikeluarkannya Surat Keputusan Menteri (SKB) tiga menteri, yaitu Menteri Keuangan, Menteri Perindustrian dan Menteri Perdagangan, No. Kep. 122/ MK/2/1974, No. 32/M/SK/2/1974 dan No. 30/KPB/I/74 tertanggal 7 Februari 1974 tentang Perizinan Usaha Leasing dan disempurnakan Keputusan Menteri Keuangan No. 1251/KMK.013/1988 tanggal 20 Desember 1988.

Leasing (Sewa Guna Usaha) adalah suatu kegiatan pembiayaan dalam bentuk penyediaan barang modal baik secara sewa guna usaha dengan hak opsi maupun sewa usaha tanpa hak opsi untuk digunakan oleh lesse selama jangka waktu tertentu 
berdasarkan perjanjian kedua belah pihak.

Munculnya lembaga pembiayaan / leasing ini merupakan suatu alternatif yang menarik bagi pengusaha dan masyarakat, karena saat ini sulit untuk mendapatkan dana. Sedangkan melalui Leasing mereka bisa memperoleh dana untuk pembelian barang-barang modal dan kendaraan bermotor dalam jangka waktu tertentu.

Harus diakui bahwa bagaimanapun sehatnya kebijaksanaan kredit dan betapapun sistematisnya analisis terhadap semua permohonan kredit, namun tidak semua kredit yang diberikan oleh perusahaan bisa lepas dari permasalahan dalam pembayaran kreditnya. Salah satu permasalahan yang dihadapi PT. Trihamas Finance Cabang Madiun adalah ketidaktepatan debitur dalam pembayaran kreditnya, baik itu bunga maupun angsuran pokoknya.

Untuk permasalahan yang dihadapi PT Trihamas Finance Cabang Madiun adalah tunggakan angsuran kredit yang mencapai ratarata $22,5 \%$ per tahun selama empat tahun terakhir mulai tahun 2012 sampai 2015. Dimana kredit kurang lancar rata-rata sebesar 9,25\%,kredit diragukan rata - rata sebesar $11 \%$ dan kredit macet rata - rata sebesar $2,25 \%$.

Sebelum pihak leasing menyetujui permohonan kredit calon debitur, maka leasing akan melakukan analisa kredit. Dalam hal ini analisa kredit digunakan sebagai alat untuk mendapatkan informasi tentang calon debitur, sehingga diharapkan kredit yang diberikan benar-benar digunakan oleh calon debitur untuk memajukan usahanya.
Menurut Hasymi Ali (1995:122), analisa kredit adalah bidang dimana para peneliti telah mencurahkan banyak waktu dan usaha untuk menghasilkan modelmodel operasi leasing yang normatif.

Definisi lain menurut M.Muslich (1997:173) analisa kredit adalah suatu proses untuk mengevaluasi apakah nasabah dapat diberikan kredit atau tidak.

Sedangkan

menurut

Hadiwijaya (2000:1) analisa kredit adalah suatu proses untuk mengetahui bahwa suatu kredit itu diberikan oleh lembaga-lembaga kredit baik bank maupun non bank, dimana semua pemberi kredit mengharapkan kredit yang diberikannya dapat dipergunakan secara maksimal oleh para debitur.

Menurut Dahlan Siamat ( 2004 : 171 ) prinsip perkreditan disebut pula konsep 5C yaitu character, capacity, capital, collateral dan condition of economic, pada dasarnya konsep 5C ini dapat memberikan informasi mengenai itikad baik (willing to play) dan kemampuan membayar (ability to pay) nasabah untuk melunasi kembali pinjaman beserta bunganya.

Berdasarkan uraian di atas bias disimpulkan bahwa penilaian kredit sangat penting agar dapat diperoleh data tentang analisa $5 C$ yaitu character, capacity, capital, collateral dan condition of economic. Dengan melihat semua aspek di atas, diharapkan dapat diketahui kemampuan calon debitur dalam mengelola fasilitas kredit yang diterimanya sebagai tambahan modal sehingga kemungkinan timbulnya kredit bermasalah dapat ditekan.

Untuk mengetahui bagaimana variabel - variabel analisa pembiayaan dalam kontribusinya 
terhadap keputusan pemberian pembiayaan tersebut maka peneliti akan melakukan penelitian dengan judul "Pengaruh Penilaian Pembiayaan terhadap Keputusan Pemberian Pembiayaan Kredit mobil pada Pt. Trihamas Finance Cabang Madiun".

Dari latar belakang yang diuraikan secara singkat diatas, maka rumusan masalah dalam penelitian ini diuaraikan sebagai berikut :

1.Apakah Character, Capacity, Capital, Collateral dan Condition of economi berpengaruh terhadap keputusan penilaian pemberian kredit pada PT Trihamas Finance Cabang Madiun secara parsial?

2.Apakah Character, Capacity, Capital, Collateral dan Condition of economi berpengaruh terhadap keputusan penilaian pemberian kredit pada PT Trihamas Finance Cabang Madiun secara simultan?

Tujuan dari penelitian ini adalah sebagai berikut :

1. Untuk memberikan bukti empirisCharacter, Capacity, Capital, Collateral dan Condition of economi berpengaruh secara parsial terhadap keputusan penilaian pemberian pembiayaan pada PT Trihamas Finance Cabang Madiun.

2. Untuk memberikan bukti empiris Character, Capacity, Capital, Collateral dan Condition of economi berpengaruh secara simultan terhadap keputusan penilaian pemberian pembiayaan pada PT Trihamas Finance Cabang Madiun

\section{METODE PENELITIAN}

Penelitian ini dilakukan di PT. Trihamas Finance Cabang Madiun. Adapun waktu pelaksanaan penelitian adalah Waktu penelitian yaitu direncanakan selama 5 bulan dari bulan September 2016 yang dimulai dari pengajuan judul sampai dengan penyelesaian penulisan laporan penelitian pada bulan Januari 2017

Populasi adalah wilayah generalisasi yang terdiri atas objek atai subjek yang memiliki kualitas dan karakteristik tertentu yang ditetapkan oleh peneliti untuk dipelajari dan kemudian ditarik kesimpulannya Sugiyono (2013). Populasi dalam penelitian ini adalah semua debitur yang menerima kredit bermotor selama tahun 2016 pada PT Trihamas Finance Cabang Madiun yaitu sebesar 300 debitur.

Menurut Sugiyono (2006:74), sample adalah bagian dari jumlah dan karakteristik yang dimiliki oleh populasi tersebut. Dalam pemilihan sampel pada penelitian ini menggunakan metode Probability Sampling, adalah teknik pengambilan sampel yang memberi peluang / kesempatan yang sama bagi setiap unsur atau anggota populasi untuk dipilih menjadi sampel (Sugiyono, 2006:77).

Menurut Suharsimi Arikunto (2003: 120), apabila jumlah populasi kurang dari 100 lebih baik diambil semua sehingga penelitiannya merupakan penelitian populasi. Selanjutnya jika jumlah populasinya besar dapat diambil antara $10-15 \%$ atau $20-25 \%$ atau lebih.

Dalam penelitian ini populasi yang digunakan adalah sebesar 300 debitur. Agar hasil dari penelitian ini 
cukup akurat kebenarannya, maka dari populasi sebesar 300 debitur diambil sebagian (sampel) yaitu $25 \%$ dari populasi yang ada di lokasi penelitian sehingga terkumpul sebanyak 75 orang yang menjadi sampel.

Instrumen pengumpulan data pada penelitian ini adalah angket atau kuesioner. Menurut Arikunto (2006:151) angket atau kuesioner adalah pernyataan tertulis yang digunakan untuk memperoleh informasi dari responden dalam arti laporan tentang pribadi atau hal-hal yang ia ketahui.

Angket yang digunakan dalam penelitian ini adalah angket tertutup dengan kemungkinan jawaban yang telah tersedia. Mengenai alternative jawaban dalam angket, penulis menggunakan skala ordinal. Menurut Sugiyono (2013) skala likert adalah skala pengukuran yang tidak hanya menyatakan kategori, tetapi juga menyatakan peringkat construct yang diukur.

Untuk setiap pilihan jawaban diberi skor, maka responden harus menggambarkan, mendukung pernyataan (item positif) atau tidak mendukung pernyataan (item negatif). Skor atas pilihan jawaban untuk kuesioner yang diajukan untuk pernyataan positif adalah sangat setuju (5), setuju (4), kurang setuju (3), tidak setuju (2) ,sangat tidak setuju (1).

Dalam penelitian ini digunakan empat variabel penelitian yaitu Character $\left(\mathrm{X}_{1}\right)$, Capacity $\left(\mathrm{X}_{2}\right)$, Capital $\left(\mathrm{X}_{3}\right)$, Collateral $\left(\mathrm{X}_{4}\right)$, Condition of economy $\left(\mathrm{X}_{5}\right)$ dan Keputusan Pemberian Kredit (Y).
Character adalah watak dan perilaku seseorang baik secara individual maupun dalam komunitas atau lingkungan usahanya ( Dahlan Siamat 2004 : 171 )

Capacity adalah kemampuan peminjam dalam mengelola usahanya secara sehat untuk kemudian memperoleh laba sesuai yang diperkirakan ( Dahlan Siamat 2004 : 171 ).

Capital adalah modal yang memadai untuk menjalankan dan memelihara kelangsungan usahanya ( Dahlan Siamat 2004 : 171 ).

Collateral adalah barang jaminan yang diserahkan debitur sebagai jaminan atas kredit bank yang diperolehnya ( Dahlan Siamat 2004 : 171

Condition of economy adalah keadaan perekonomian yang secara langsung mempengaruhi kegiatan usaha debitur. ( Dahlan Siamat 2004 : 171 )

Dari kelima hal dihatas digunakan sebagai bahan pertimbangan untuk melakukan keputusan pemberian kredit. Keputusan Pemberian Pembiayaan / Kredit adalah kesepakatan atau persetujuan pinjam meminjam antara bank dengan pihak lain yang mewajibkan pihak peminjam untuk melunasi hutangnya setelah jangka waktu tertentu dengan jumlah bunga, imbalan, atau pembagian hasil keuntungan.

Uji validitas dilakukan melalui analisis data Correlated-Item Total Correlation yaitu dengan cara mengkorelasikan masing-masing skor item dengan skor total dan melakukan korelasi terhadap nilai koefisien 
korelasi dengan dasar pengambilan keputusan Jika nilai $r_{\text {hitung }}>r_{\text {tabel }}$, maka pernyataan dalam kuesioner dinyatakan valid, sedangkan jika nilai $r_{\text {hitung }}<r_{\text {tabel }}$, maka item pertanyaan dalam kuesioner dinyatakan tidak valid. Ghozali (2013:53).

Uji reliabilitas dengan cara melihat Cronbach Alpha dengan signifikansi yang digunakan lebih besar dari 0,70. Suatu konstruk atau variable dikatakan reliable jika memberikan nilai Cronbach Alpha> 0,70 (Ghozali, 2013:48).

Uji asumsi Normalitas menggunakan metode KolmogrovSmirnov jika hasil angka signifikansi (Sig) lebih kecil dari 0,05 maka data tidak terdistribusi normal. Ghozali (2013:160). Uji heteroskedastisitas adalah dengan melihat grafik scatterplot antaranilai prediksi variabel terikat (ZPRED) dengan residualnya (SRESID). Dasar pengambilan keputusan uji tersebut yaitu jika ada titik-titik yang membentuk pola tertentu yang teratur seperti bergelombang, melebar kemudian menyempit, maka mengindikasikan adanya heteroskedastisitas. Jika tidak terdapat pola tertentu yang jelas, serta titiktitik menyebar diatas dan dibawah angka nol pada sumbu Y maka mengindikasikan tidak terjadi heteroskedastisitas. Menurut Ghozali (2013:139).

Uji Autokorelasi dilihat dari uji DurbinWaston (DW Test). Dengan dasar pengampilan keputusan jika Du $<\mathrm{d}<4$-du maka dinyatakan tidak terdapat autokorelasi. Ghozali (2013:110) .

Uji multikolinieritas dilakukan dengan melihat nilai tolerance dan lawannya (2) variance inflation factor ( VIF ). Jika nilai tolerance yang rendah sama dengan nilai VIF tinggi ( karena VIF $=1 /$ Tolerance $)$. Nilai cut off yang umum dipakai untuk menunjukkan adanya multikolinieritas adalah Nilai Tolerance $\leq 0,10$ atau sama dengan nilai VIF $\geq 10$. Ghozali (2013:105).

Teknik analisis data yang dipaki adalah regresi linier berganda (multiple regression). Untuk menguji pengaruh variabel penelitian secara parsial digunakan uji t. Dengan dasar pengambilan keputusan bila $t_{\text {hitung }}>$ $\mathrm{t}_{\text {tabel }}$ pada $\alpha=0,05$ artinya variabel independen secara parsial mempengaruhi variabel dependen. Bila $\mathrm{t}_{\text {hitung }}<\mathrm{t}_{\text {tabel }}$ pada $\alpha=0,05$ artinya variabel independen secara parsial tidak mempengaruhi variabel dependen. Ghozali (2013:98).

Untuk menguji pengaruh variabel penelitian secara simultan digunakan uji F. Dengan dasar pengambilan keputusan bila $F_{\text {hitung }}>F_{\text {tabel }}$ pada $\alpha=0,05$ artinya variabel independen secara simultan mempengaruhi variabel dependen. Bila $F_{\text {hitung }}<F_{\text {tabel }}$ pada $\alpha=0,05$ artinya variabel independen secara simultan tidak mempengaruhi variabel dependen. Ghozali (2013).

\section{HASIL PENELITIAN DAN PEMBAHASAN}

Untuk mengetahui pengaruh Character $\left(\mathrm{X}_{1}\right)$, Capacity $\left(\mathrm{X}_{2}\right)$, Capital $\left(\mathrm{X}_{3}\right)$, Collateral $\left(\mathrm{X}_{4}\right)$, Condition of economy $\left(\mathrm{X}_{5}\right)$ dan Keputusan Pemberian Kredit (Y), melakukan uji regresi linier berganda. Berikut ini hasil uji regresi berganda: 
Hasil Analisis Regresi Linier berganda

\begin{tabular}{|c|c|c|c|c|c|c|c|c|}
\hline \multirow[b]{2}{*}{ Model } & & \multicolumn{2}{|c|}{ Unstandardided Coefficients } & \multirow{2}{*}{\begin{tabular}{c|} 
Standardized \\
Coefficints \\
Betia \\
\end{tabular}} & \multirow[b]{2}{*}{$t$} & \multirow[b]{2}{*}{ Sig. } & \multicolumn{2}{|c|}{ Collinearity Statistics } \\
\hline & & $B$ & Stat Error & & & & Tolerance & $\mathrm{VF}_{\mathrm{F}}$ \\
\hline \multirow[t]{6}{*}{1} & (Constant) & 5.977 & .420 & & 14.240 & .000 & & \\
\hline & Character (Xi) & .174 & .051 & .278 & 3.404 & .001 & 254 & 3.943 \\
\hline & $\operatorname{Capach}\left(\alpha_{2}\right)$ & .233 & .046 & .328 & 5044 & .000 & 399 & 2507 \\
\hline & Capital (X3) & .108 & .043 & .150 & 2491 & .015 & .469 & 2.134 \\
\hline & Collateral (Xt) & .136 & .041 & .228 & 3.356 & .001 & 366 & 2.733 \\
\hline & Condtion of Economy $\left(X_{5}\right)$ & .108 & .020 & .251 & 5.523 & .000 & .820 & 1.220 \\
\hline
\end{tabular}

Berikut adalah persamaan regresi linier berdasarkan hasil analisisi di atas:

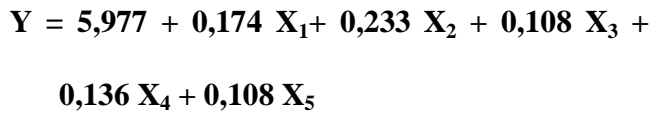

Dari persamaan model regresi diatas dapat diinterpretasikan sebagai berikut:

1) Konstanta regresi sebesar 5,977 berarti apabila seluruh variabel bebas $\left(\mathrm{X}_{1}\right.$ sampai dengan $\mathrm{X}_{5}$ ) diabaikan, maka keputusan pemberian pembiayaan (Y) sebesar 5,977 satuan.

2) Koefisien variabel bebas karakter/character $\left(\mathrm{X}_{1}\right)$ sebesar 0,174 , berarti setiap penambahan 1 satuan variabel karakter/character $\quad\left(\mathrm{X}_{1}\right)$, sementara variabel bebas lainnya $\left(X_{2}, \quad X_{3}, \quad X_{4}, X_{5}\right)$ dianggap konstan, maka keputusan pemberian pembiayaan akan meningkat 0.174 satuan.

3) Koefisien variabel bebas kapasitas/ capacity $\left(\mathrm{X}_{2}\right)$ sebesar 0,233, berarti setiap penambahan 1 satuan variabel kapasitas/ capacity $\left(\mathrm{X}_{2}\right)$, sementara variabel bebas lainnya $\left(X_{1}, \quad X_{3}, \quad X_{4}, X_{5}\right)$ dianggap konstan, maka keputusan pemberian pembiayaan akan meningkat 0.233 satuan.

4) Koefisien variabel bebas modal/ capital $\left(\mathrm{X}_{3}\right)$ sebesar 0,108, berarti setiap penambahan 1 satuan variabel modal/ capital $\left(\mathrm{X}_{3}\right)$, sementara variabel bebas lainnya $\left(X_{1}, X_{2}\right.$, $\left.X_{4}, X_{5}\right)$ dianggap konstan, maka keputusan pemberian pembiayaan akan meningkat 0.108 satuan.

5) Koefisien variabel bebas barang jaminan/ collateral $\left(\mathrm{X}_{4}\right)$ sebesar 0,136, berarti setiap penambahan 1 satuan variabel barang jaminan/ collateral $\left(X_{4}\right)$, sementara variabel bebas lainnya $\left(X_{1}, X_{2}, X_{3}, X_{5}\right)$ dianggap konstan, maka keputusan pemberian pembiayaan akan meningkat 0.136 satuan.

6) Koefisien variabel bebas kondisi ekonomi/ condition of economy $\left(X_{5}\right)$ sebesar 0,108, berarti setiap penambahan 1 satuan variabel kondisi ekonomi/condition of economy $\left(X_{5}\right)$, sementara variabel bebas lainnya $\left(X_{1}, X_{2}, X_{3}, X_{4}\right)$ dianggap konstan, maka keputusan pemberian pembiayaan akan meningkat 0.108 satuan.

Uji $t$ dipergunakan untuk menguji signifikansi pengaruh variabel bebas $\left(\mathrm{X}_{1}-\mathrm{X}_{5}\right)$ secara parsial terhadap variabel terikat (Y). Dalam hal ini untuk menguji pengaruh variabel karakter (character)/ $\mathrm{X}_{1}$, kapasitas (capacity)/ $\mathrm{X}_{2}$, modal (capital) $/ \mathrm{X}_{3}$, barang jaminan (collateral) $/ \mathrm{X}_{4}$ dan kondisi ekonomi (condition of economy) $/ \mathrm{X}_{5}$ secara parsial terhadap keputusan pemberian pembiayaan di PT Trihamas Finance Cabang Madiun 
Tabel 4.31

Pengujian Pengaruh Variabel Bebas $\left(\mathrm{X}_{1}-\mathrm{X}_{5}\right)$ terhadap Variabel Terikat Secara Parsial/Y (Uji t)

\begin{tabular}{|c|c|c|l|}
\hline Variabel & t hitung & t tabel & Keterangan \\
\hline $\begin{array}{c}\text { Karakter } \\
(\text { Character }) / \mathrm{X}_{1}\end{array}$ & 3,404 & 1,9930 & Sign \\
\hline $\begin{array}{c}\text { Kapasitas } \\
(\text { Capacity)/X }\end{array}$ & 5,044 & 1,9930 & Sign \\
\hline $\begin{array}{c}\text { Modal } \\
(\text { Capital }) / \mathrm{X}_{3}\end{array}$ & 2,491 & 1,9930 & Sign \\
\hline $\begin{array}{c}\text { Barang Jaminan } \\
(\text { Collateral }) / \mathrm{X}_{4}\end{array}$ & 3,356 & 1,9930 & Sign \\
\hline $\begin{array}{c}\text { Kondisi } \\
\text { Ekonomi } \\
(\text { Condition of } \\
\text { economy)/X }\end{array}$ & 5,523 & 1,9930 & Sign \\
\hline
\end{tabular}

Hasil uji t seperti terlihat pada Tabel 4.31 menunjukkan seluruh variabel bebas yaitu variabel karakter (character)/ $\mathrm{X}_{1}$, kapasitas (capacity)/ $\mathrm{X}_{2}$, modal (capital)/ $\mathrm{X}_{3}$, barang jaminan (collateral)/ $\mathrm{X}_{4}$ dan kondisi ekonomi (condition of economy)/ $\mathrm{X}_{5}$ berpengaruh signifikan secara parsial terhadap keputusan pemberian pembiayaan di PT Trihamas Finance Cabang Madiun

Berikut adalah persamaan regresi berdasarkan hasil analisisi di atas :

$$
Y=\underset{0,042 X_{1} X_{3}+0,118 X_{2} X_{3}+e}{4,318-0,028 X_{1}+0,094 X_{2}+0,451 X_{3}-}
$$

Uji $\mathrm{F}$ dipergunakan untukmenguji pengaruh seluruh variabel bebas yaitu variabel karakter (character)/ $\mathrm{X}_{1}$, kapasitas (capacity)/ $\mathrm{X}_{2}, \quad$ modal (capital)/ $\mathrm{X}_{3}$, barang jaminan (collateral)/ $\mathrm{X}_{4}$ dan kondisi ekonomi (condition of economy)/ $\mathrm{X}_{5}$ secara simultan terhadap keputusan pemberian pembiayaan di PT Trihamas Finance Cabang Madiun.

Pengolahan data dengan menggunakan software SPSS untuk uji F dapat dilihat pada Tabel 4.32

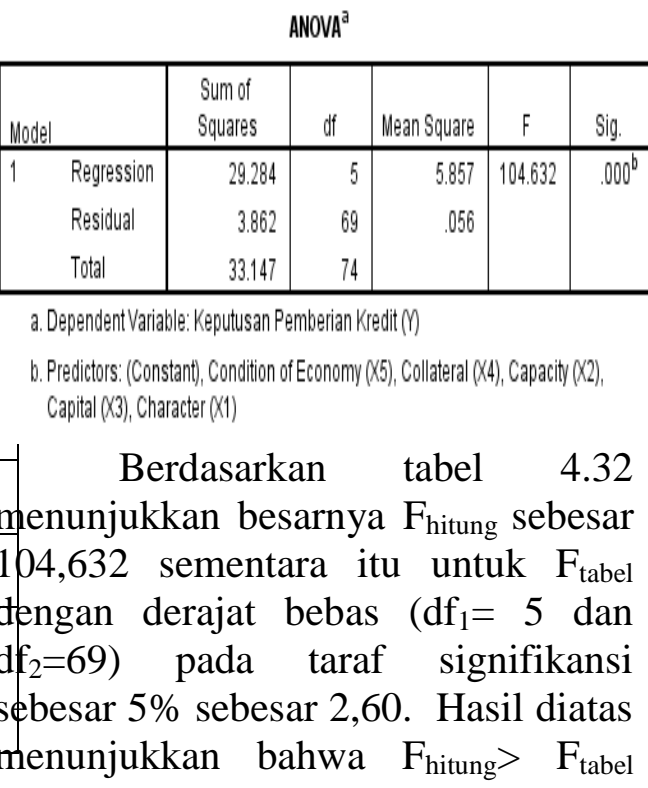
yang menghasilkan keputusan pengujian hipotesis yaitu $\mathrm{H}_{0}$ ditolak. Hasil pengujian dapat diambil kesimpulan bahwa variabel bebas yaitu variabel karakter (character)/ $\mathrm{X}_{1}$, kapasitas (capacity)/ $\mathrm{X}_{2}$, modal (capital)/ $\mathrm{X}_{3}$, barang jaminan (collateral)/ $\mathrm{X}_{4}$ dan kondisi ekonomi (condition of economy)/ $\mathrm{X}_{5}$ secara simultan terhadap keputusan pemberian pembiayaan di PT Trihamas Finance Cabang Madiun.

Berdasarkan hasil penelitian dapat dilakukan pembahasan hasil penelitian sebagai berikut:

1. Variabel bebas penelitian meliputi variabel karakter (character)/ $\mathrm{X}_{1}$, kapasitas (capacity)/ $\mathrm{X}_{2}$, modal (capital) $/ \mathrm{X}_{3}$, barang jaminan (collateral)/ $\mathrm{X}_{4}$ dan kondisi ekonomi (condition of economy) $/ \mathrm{X}_{5}$

Hasil penelitian menunjukkan untuk variabel bebas yang meliputi 5 (lima) variabel bebas menunjukkan skor penilaian yang bervariasi satu dengan yang lainnya.

Pada beberapa variabel bebas menunjukkan skor penilaian yang paling rendah dibandingkan 
dengan variabel bebas lainnya. Diantaranya adalah variabel karakter (character)/ $\mathrm{X}_{1}$. Ketiga indikator variabel karakter (character)/ $\mathrm{X}_{1}$ memiliki skor penilaian yang rata-rata mendekati netral. Indikator pertama itikad baik dan tanggung jawab dengan skor rata-rata 2.76 (netral), indikator selanjutnya sifat atau watak/gaya hidup dengan skor rata-rata 3.01 (netral) dan indikator komitmen pembayaran dengan skor rata-rata 3.41 (netral).

Variabel selanjutnya yang memiliki skor penilaian terendah setelah variabel karakter (character)/ $\mathrm{X}_{1}$ adalah variabel barang jaminan (collateral)/ $\mathrm{X}_{4}$. Skor penilaian pada variabel barang jaminan (collateral)/ $\mathrm{X}_{4}$ rata-rata mulai dari netral sampai dengan paling tinggi setuju.

Indikator kepemilikan barang jaminan dan keaslian dokumen memiliki rata-rata 3.15 (netral), sementara itu indikator jaminan bersifat fisik dan non fisik dengan skor rata-rata 3.59 (setuju) dan indikator nilai barang yang dijaminkan sebanding atau lebih tinggi dari plafond kredit dengan skor rata-rata 3.61 (setuju).

Variabel yang memiliki skor penilaian paling baik adalah variabel modal (capital)/ $\mathrm{X}_{3}$. Hasil skor penilaian variabel modal (capital)/X $\mathrm{X}_{3}$ rata-rata menjawab setuju. Indikator variabel ini yang memiliki skor tertinggi adalah memiliki tabungan atau simpanan di bank dengan skor rata-rata 4.33 (setuju), selanjutnya indikator memiliki usaha lain sebagai sumber penghasilan dengan skor rata-rata 4.13 (setuju) dan terakhir indikator memiliki sumber penghasilan tetap dengan skor ratarata 3.83 (setuju).

Variabel selanjutnya yang memiliki skor penilaian tertinggi adalah variabel kondisi ekonomi (condition of economy)/ $\mathrm{X}_{5}$. Variabel kondisi ekonomi memiliki skor rata-rata penilaian setuju. Indikator variabel kondisi ekonomi yang memiliki skor ratarata tertinggi adalah iklim pengembangan bisnis, usaha dan investasi dengan skor rata-rata 4.00 (setuju), selanjutnya indikator kebijakan moneter pemerintah atau fluktuasi perekonomian dengan skor rata-rata 3.99 (setuju) dan indikator keadaan ekonomi masyarakat dengan skor rata-rata 3.80 (setuju).

Variabel yang menempati skor penilaian tertinggi selanjutnya adalah variabel kapasitas (capacity)/ $\mathrm{X}_{2}$. Variabel kapasitas memiliki skor rata-rata mulai dari netral sampai dengan setuju. Indikator variabel kapasitas yang memiliki rata-rata paling tinggi adalah kemampuan dalam menyelesaikan kredit tepat waktu dengan skor rata-rata 4.09 (setuju). Selanjutnya indikator kemampuan membayar angsuran dengan skor rata-rata 3.85 (setuju). Indikator variabel kapasitas yang memiliki skor rata-rata penilaian netral adalah indikator pendapatan nasabah dengan skor rata-rata penilaian 3.37 (netral).

2. Keputusan Pemberian Pembiayaan di PT Trihamas Finance Cabang Madiun

$\begin{array}{lr}\text { Hasil } & \text { penelitian } \\ \text { menunjukkan } & \text { keputusan } \\ \text { pemberian pembiayaan di PT } \\ \text { Trihamas Finance Cabang Madiun } \\ \text { adalah cukup baik. Hasil deskripsi } \\ \text { variabel keputusan pemberian }\end{array}$


pembiayaan rata-rata menjawab setuju dan sangat setuju.

Hasil tersebut dapat dilihat dari penilaian terhadap variabel keputusan pemberian pembiayaan pada setiap indikator cukup baik. Indikator pertama yaitu keyakinan kreditur atas kemampuan debitur membayar angsuran dengan skor rata-rata 4.35 (setuju), kemudian indikator kedua keyakinan kreditur atas kemampuan debitur mengembalikan pinjaman tepat waktu dengan skor rata-rata 4.95 (sangat setuju) dan indikator ketiga yaitu keyakinan kreditur atas kemampuan debitur memenuhi perjanjian kredit yang telah disepakati dengan skor rata-rata 4.92 (sangat setuju) sesuai Hasil penelitian yang dilakukan Ni Made Dwi Widiantari, I Wayan Suwendra, Fridayana Yudiatmaja tahun 2014. Hasil penelitian menunjukkan bahwa penilaian kredit berpengaruh signifikan terhadap keputusan pemberian kredit

3. Pengaruh variabel bebas $\left(X_{1}, X_{2}\right.$, $\mathrm{X}_{3}, \mathrm{X}_{4}, \mathrm{X}_{5}$ ) secara parsial terhadap variabel terikat (Y) yaitu keputusan pemberian pembiayaan di PT Trihamas Finance Cabang Madiun.

Dari hasil pengujian hipotesis menunjukkan kelima variabel bebas meliputi variabel karakter (character) $/ \mathrm{X}_{1}, \quad$ kapasitas (capacity)/ $\mathrm{X}_{2}$, modal (capital) $/ \mathrm{X}_{3}$, barang jaminan (collateral)/ $\mathrm{X}_{4}$ dan kondisi ekonomi (condition of economy) $/ \mathrm{X}_{5}$ berpengaruh secara parsial terhadap keputusan pemberian pembiayaan di PT Trihamas Finance Cabang Madiun (Y).

Hal tersebut dapat dilihat dari nilai $\mathrm{t}$ hitung $\mathrm{X}_{1}=3.404, \mathrm{t}$ hitung $X_{2}=5,044$, $t$ hitung $X_{3}=$ 2,491, $t$ hitung $X_{4}=3,356$ dan $t$ hitung $\mathrm{X}_{5}=5,523$ seluruhnya lebih besar dari t tabel sebesar 1,9930.

Variabel kondisi ekonomi (condition of economy) $/ \mathrm{X}_{5}$ merupakan variabel bebas yang memiliki pengaruh paling dominan terhadap keputusan pemberian pembiayaan di PT Trihamas Finance Cabang Madiun. Hal tersebut dapat dilihat dari nilai $\mathrm{t}$ hitung variabel $\mathrm{X}_{5}$ sebesar 5,523 paling besar dibandingkan dengan variabel bebas lainnya.

Hasil ini mengindikasikan bahwa kondisi ekonomi yang terjadi saat ini menjadi variabel yang paling berpengaruh terhadap keputusan pemberian pembiayaan pada nasabah khususnya yang terjadi pada PT Trihamas Finance Cabang Madiun. Variabel kondisi ekonomi dapat terjadi diantaranya adalah kebijakan moneter dari pemerintah, iklim usaha yang sedang terjadi yang mendorong pengembangan bisnis, usaha dan investasi, serta kondisi ekonomi yang sedang dialami masyarakat. Variabel bebas berikutnya yang paling dominan mempengaruhi keputusan pemberian pembiayaan di PT Trihamas Finance Cabang Madiun adalah variabel kapasitas (capacity)/ $\mathrm{X}_{2}$ dengan nilai t hitung sebesar 5,044.

Kapasitas yang meliputi kemampuan debitur mengelola usahanya secara sehat untuk kemudian mampu memperoleh laba menjadi faktor selanjutnya yang mempengaruhi keputusan pemberian pembiayaan. Kapasitas debitur menjadi sangat penting karena berhubungan dengan kemampuannya mengembalikan pinjaman yang disediakan kreditur 


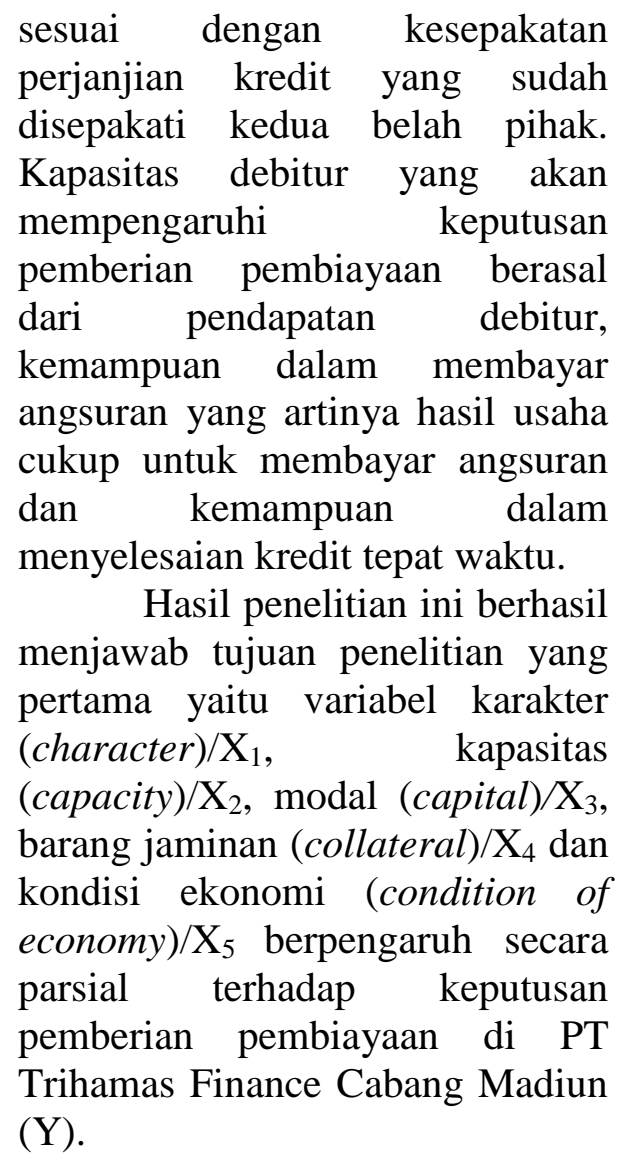

4. Pengaruh variabel bebas $\left(X_{1}, X_{2}\right.$, $\left.\mathrm{X}_{3}, \mathrm{X}_{4}, \mathrm{X}_{5}\right)$ secara simultan terhadap variabel terikat (Y) yaitu keputusan pemberian pembiayaan di PT Trihamas Finance Cabang Madiun.

Dari hasil pengujian variabel bebas menunjukkan bahwa kelima variabel bebas meliputi variabel karakter (character) $/ \mathrm{X}_{1}, \quad$ kapasitas (capacity) $/ \mathrm{X}_{2}, \quad$ modal (capital) $/ \mathrm{X}_{3}$, barang jaminan (collateral) $/ \mathrm{X}_{4}$ dan kondisi ekonomi (condition of economy)/ $\mathrm{X}_{5}$ berpengaruh secara simultan terhadap keputusan pemberian pembiayaan di PT Trihamas Finance Cabang Madiun. Hal tersebut sesuai penelitian yang di lakuakn oleh Dwi FeriyantoTahun 2006
Berdasarkan analisis dan pembahasan tentang pengaruh faktor 5C terhadap Keputusan dalam pengambilan kredit di PD. BPR Pati, maka dapat ditarik kesimpulan bahwa faktor $5 \mathrm{C}$ secara serentak mempunyai pengaruh signifikan terhadap Keputusan pengambilan kredit. Hal ini berarti kelima variable bebas yang terdiri dari Character $\left(\mathrm{X}_{1}\right)$, Capacity $\left(\mathrm{X}_{2}\right)$, Capital $\left(\mathrm{X}_{3}\right)$, Collateral $\left(\mathrm{X}_{4}\right)$ dan Condition of Economy $\quad\left(\mathrm{X}_{5}\right) \quad$ mempunyai pengaruh terhadap Keputusan dalam pengambilan kredit

Hasil tersebut dapat dilihat dari uji $\mathrm{F}$ yang menunjukkan nilai F hitung sebesar 104,632 lebih besar daripada $F$ tabel sebesar 2.60. Kelima variabel bebas secara keseluruhan mempengaruhi keputusan pemberian pembiayaan pada PT Trihamas Finance Cabang Madiun sebesar $88.3 \%$. Hal tersebut dapat dilihat dari koefisien determinasi $\left(\mathrm{R}^{2}\right)$ model regresi sebesar $88.3 \%$. berarti ada pengaruh variable lain sebesar $12,7 \%$.

Hasil penelitian ini berhasil menjawab tujuan penelitian yang kedua yaitu variabel karakter (character)/ $\mathrm{X}_{1}, \quad$ kapasitas (capacity)/ $\mathrm{X}_{2}$, modal (capital)/ $\mathrm{X}_{3}$, barang jaminan (collateral)/ $\mathrm{X}_{4}$ dan kondisi ekonomi (condition of economy) $/ \mathrm{X}_{5}$ berpengaruh secara simultan terhadap keputusan pemberian pembiayaan di PT Trihamas Finance Cabang Madiun.

\section{KESIMPULAN}

Berdasarkan hasil penelitian dan pengujian hipotesis dapat disimpulkan bahwa : 
1. Dari hasil pengujian hipotesis menunjukkan kelima variabel bebas meliputi variabel karakter (character)/X1, kapasitas (capacity)/X2, modal (capital)/X3, barang jaminan (collateral)/X4 dan kondisi ekonomi (condition of economy)/X5 berpengaruh secara parsial terhadap keputusan pemberian pembiayaan di PT Trihamas Finance Cabang Madiun (Y).

2. Variabel kondisi ekonomi (condition of economy) $/ \mathrm{X}_{5}$ merupakan variabel bebas yang memiliki pengaruh paling dominan terhadap keputusan pemberian pembiayaan di PT Trihamas Finance Cabang Madiun. Hal tersebut dapat dilihat dari nilai $\mathrm{t}$ hitung variabel $\mathrm{X}_{5}$ paling besar dibandingkan dengan variabel bebas lainnya.

Variabel bebas berikutnya yang paling dominan mempengaruhi keputusan pemberian pembiayaan di PT Trihamas Finance Cabang.

\section{DAFTAR PUSTAKA}

Muljono 2007. Manajemen Perkreditan bagi Bank Komersil.Yogyakarta BPFE Yogyakarta

Dahlan Siamat 2004. Manajemen Lembaga Keuangan. Jakarta Intermmedia

Djohan, Warman. 2000. Kredit Bank, Edisi 1. PT. Mutiara Sumber Widya: Jakarta

Firdaus, Rachmat dan Maya, Ariyanti. 2009. Manajemen Perkreditan Bank Umum:
Madiun adalah variabel kapasitas (capacity)/ $\mathrm{X}_{2}$

Dari hasil pengujian hipotesis pengaruh kelima variabel bebas menunjukkan bahwa kelima variabel bebas meliputi variabel karakter (character)/ $\mathrm{X}_{1}$, kapasitas (capacity)/ $\mathrm{X}_{2}$, modal (capital)/ $\mathrm{X}_{3}$, barang jaminan (collateral)/ $\mathrm{X}_{4}$ dan kondisi ekonomi (condition of economy)/ $\mathrm{X}_{5}$ berpengaruh secara simultan terhadap keputusan pemberian pembiayaan di PT Trihamas Finance Cabang Madiun.

3. Terdapat variabel lain selain (character) $/ \mathrm{X}_{1}, \quad$ kapasitas (capacity)/ $\mathrm{X}_{2}$, modal (capital)/ $\mathrm{X}_{3}$, barang jaminan (collateral)/ $\mathrm{X}_{4}$ dan kondisi ekonomi (condition of economy)/ $\mathrm{X}_{5}$ yang mempengaruhi dalam keputusan pemberian pembiayaan di PT Trihamas Finance Cabang Madiun.

Teori, Masalah, Kebijakan dan Aplikasi Lengkap dengan Analisis Kredit. Bandung: Alfabeta.

Kasmir. S.E., M.M. 2002. DasarDasar Perbankan. Jakarta: PT. Raja Grafindo Persada.

Kasmir. S.E., M.M. 2008. Bank dan Lembaga Keuangan Lainnya. Jakarta: PT. Raja Grafindo Persada.

Sutojo, Siswanto, 1997, Menangani Kredit Bermasalah, PT. Pustaka Binaman Pressindo, Jakarta. 
Purwanto, Penilaian Pembiayaan Terhadap Keputusan Pembiayaan

Suyatno, Thomas, 2003, Dasar-Dasar Perkreditan, PT. Gramedia Pustaka. Utama, Jakarta.

Feriyanto, D. (2006). Analisis FaktorFaktor Yang Mempengaruhi Keputusan Pengambilan Kredit Modal Kerja. Skripsi tidak diterbitkan. Yogyakarta: Fakultas Ekonomi Universitas Islam Indonesia.

Sana, Naelus. (2010). Faktor-Faktor Yang Mempengaruhi Pemberian Pembiayaan Pada Baitul Maal Wat Tamwil Di Kabupaten Demak. Skripsi tidak diterbitkan. Semarang: Jurusan Ekonomi Islam Fakultas Syari'ah Institut Agama Islam Negeri Walisongo.

Widiantari, D. Ni Made, Suwendra, I Wayan dan Yudiaatmaja, Fridayana. (2014). Pengaruh Penilaian Kredit Terhadap Keputusan Pemberian Kredit Pada BPR. Jurnal Vol.2, (Online), (http://www.ejournalbisma.ac.id, Diunduh tanggal 20 Oktober 2016)

Ardiansyah, Fery. (2011). VariabelVariabel Yang Berpengaruh Terhadap Keputusan Pemberian Kredit Pada PT. BPR Surya Artha Utama Di Surabaya. Skripsi tidak diterbitkan. Surabaya: Jurusan Ilmu Administrasi Bisnis Fakultas Ilmu Sosial Dan Ilmu Politik Universitas Pembangunan Nasional Veteran Jawa Timur.
Wiguna, Dody. (2010). Variabel Variabel Yang Berpengaruh Terhadap Keputusan Pemberian Kredit Untuk Pembelian Sepeda Motor Pada PT. Suzuki Sejahtera Sidoarjo. Skripsi tidak diterbitkan. Surabaya: Jurusan Ilmu Administrasi Bisnis Fakultas Ilmu Sosial Dan Ilmu Politik Universitas Pembangunan Nasional Veteran Jawa Timur.

Hardinata, Yusvendy. (2014). Analisis Keputusan Pemberian Kredit Modal Kerja Terhadap Usaha Kecil Dan Menengah Studi Kasus Pada Bank BRI KCP Sukun Malang. Jurnal Ilmiah. Malang: Jurusan Ilmu Ekonomi Fakultas Ekonomi Dan Bisnis Universitas Brawijaya.

Dewi, A. Oktavia, Darminta dan NP Endang, G. Maria. (2014). Analisis Manajemen Guna Meminimalisir Kredit Bermasalah Studi Pada Koperasi Bank Perkreditan Rakyat Pancadana Batu. Jurnal Vol.9, No.2, (Online), (http//administrasibisnis.stude ntjournal.ub.ac.id, Diunduh tanggal 20 Oktober 2016). 
Purwanto, Penilaian Pembiayaan Terhadap Keputusan Pembiayaan

CAPITAL, VOLUME 1, NOMOR 1, SEPTEMBER 2017 | 1 